\title{
Optymalny schemat leczenia pierwszej linii chorych na chłoniaka grudkowego w 2015 roku
}

\author{
The optimal first-line regimen \\ for patients with follicular lymphoma in 2015
}

\author{
Iwona Hus \\ Samodzielna Pracownia Hematoonkologii Doświadczalnej, Uniwersytet Medyczny, Lublin
}

\begin{abstract}
Streszczenie
Chtoniaki indolentne to grupa nowotworów uktadu chtonnego, których wspólna cecha jest powolny, zwykle wieloletni przebieg kliniczny. Najczestszym z nich jest chtoniak grudkowy (FL), w zwiazku z czym jego leczenie jest najlepiej zdefiniowane. Aktualnym standardem leczenia FL we wczesnych stadiach klinicznych (stadia I lub II bez masywnych zmian weztowych wg klasyfikacji Ann Arbor) jest radioterapia ograniczona do miejsc zmienionych chorobowo w dawce 24 Gy. U chorych na $F L$, jak również inne chtoniaki indolentne $w$ zaawansowanych stadiach klinicznych z mata masa guza bez objawów klinicznych optymalnym sposobem postępowania pozostaje strategia „watch and wait”. W przypadku wystapienia wskazań do rozpoczecia leczenia należy zastosować immunochemioterapie z rytuksymabem. Optymalnego schematu leczenia nie określono, a wybór powinien zależeć od indywidualnej sytuacji klinicznej z uwzglednieniem czynników zależnych zarówno od choroby, jak i od pacjenta (wiek, stan wydolności fizycznej, choroby wspótistniejace). Należy wziać pod uwage nie tylko skuteczność leczenia, ale również jego toksyczność oraz wplyw na jakość życia.
\end{abstract}

Słowa kluczowe: chłoniaki indolentne, leczenie

Hematologia 2015; 6, 2: 129-135

\begin{abstract}
Indolent lymphoma are a group of lymphoid malignancies, whose common feature is slow, usually long-term clinical course. The most frequent of these is follicular lymphoma (FL) and therefore the treatment of patients with FL is best defined. The current standard of care for patients with FL in early clinical stages (limited non-bulky stage I or II) is radiotherapy limited to the involved fields at a dose of 24 Gy. In asymptomatic patients with FL and with the other indolent lymphoma in advanced stages (III and IV) with low-tumor burden, observation ("watch and wait") remains the optimal strategy. Upon occurrence of the indications for treatment, immunochemotherapy with rituximab should be used. The optimal treatment regimen for indolent lymphoma has not been established so making treatment decisions one should take into account disease status, efficacy and toxicity of the regimen as well as patient-related factors (age, performance status, comorbidities) and the impact of treatment on quality of life.
\end{abstract}

Key words: indolent lymphoma, therapy

Hematologia 2015; 6, 2: 129-135

Adres do korespondencji: Iwona Hus, Samodzielna Pracownia Hematoonkologii Doświadczalnej, Uniwersytet Medyczny, ul. Staszica 11, 20-081 Lublin, tel. 815345 468, faks 815345 605, e-mail: iwonach.hus@gmail.com 


\section{Wprowadzenie}

Chłoniaki indolentne to grupa nowotworów układu chłonnego, których wspólną cechą jest powolny, zwykle wieloletni, przebieg kliniczny. Określenie „chłoniaki indolentne” obejmuje kilka typów chłoniaków B-komórkowych, takich jak: chłoniak grudkowy (FL, follicular lymphoma), chłoniaki strefy brzeżnej (MZL, marginal zone lymphoma), chłoniak limfoplazmocytowy (LPL, lymphoplasmacytic lymphoma), chłoniak $\mathrm{z}$ małych limfocytów (SLL, small lymphocytic lymphoma). Najczęstszym $z$ nich jest FL, który stanowi ponad $70 \%$ przypadków chłoniaków indolentnych [1]. $Z$ tego względu chorzy na FL stanowią większość pacjentów uczestniczących $\mathrm{w}$ randomizowanych badaniach klinicznych dotyczących chłoniaków indolentnych, co sprawia, że leczenie chorych na FL jest najlepiej zdefiniowane. W pracy przedstawiono aktualne zasady leczenia I linii chorych na FL, jak również wyniki badań klinicznych $z$ ostatnich lat dotyczących optymalizacji terapii.

\section{Leczenie FL we wczesnych stadiach klinicznych}

Chorzy $\mathrm{z}$ rozpoznaniem FL we wczesnych stadiach klinicznych (stadium I lub II bez masywnych zmian węzłowych wg klasyfikacji Ann Arbor) stanowią jedynie 10-15\% wszystkich chorych na FL. $\mathrm{W}$ przeciwieństwie do zaawansowanych stadiów klinicznych FL, w stadiach wczesnych możliwe jest wyleczenie choroby. Zgodnie $z$ opublikowanymi w 2014 roku zaleceniami ESMO (European Society for Medical Oncology) [2] i NCCN (National Comprehensive Cancer Network) [3] standardem jest zastosowanie radioterapii ograniczonej do miejsc zmienionych chorobowo (IFRT, involved-fields radiotherapy) w dawce 24 Gy. Wyniki randomizowanego badania klinicznego 3. fazy wykazały, że podanie większej dawki nie przynosi większej korzyści terapeutycznej [4]. Taki sposób postępowania pozwala uzyskać u większości chorych wieloletnie przeżycie wolne od objawów choroby, może również potencjalnie doprowadzić do jej wyleczenia, chociaż u części chorych obserwuje się nawroty poza obszarem napromieniania [5, 6]. Odsetki przeżyć całkowitych (OS, overall survival) po 10 latach obserwacji wynoszą $60-80 \%$, a mediana przeżycia — około 19 lat [7]. Pewne zastrzeżenia może budzić fakt, że większość badań, stanowiących podstawę aktualnie obowiązujących zaleceń, miała charakter retrospektywny i przeprowadzono je przed wprowadzeniem rytuksymabu do leczenia chłoniaków B-komórkowych, w związku z czym, $\mathrm{w}$ żadnym nie porównywano radioterapii $\mathrm{z}$ aktualnie dostępnymi metodami leczenia. Niestety, przeprowadzenie randomizowanych badań klinicznych służących porównaniu skuteczności radioterapii, immunoterapii lub sekwencyjnego zastosowania obu tych metod w odniesieniu do OS jest trudne $z$ powodu stosunkowo niewielkiej liczby chorych, u których rozpoznaje się FL we wczesnych stadiach klinicznych, jak również przewlekłego wieloletniego przebiegu choroby.

Biorąc pod uwagę istotne różnice dotyczące postępowania klinicznego we wczesnych i uogólnionych stadiach klinicznych FL, bardzo ważne znaczenie ma dokładne określenie stadium zaawansowania chłoniaka, w którym coraz większą rolę przypisuje się badaniu metodą pozytonowej tomografii emisyjnej/tomografii komputerowej (PET, positron emission tomography/CT, computed tomography).

W przypadku leczenia paliatywnego dawka radioterapii, którą należy zastosować, wynosi $4 \mathrm{~Gy}$ podane w dwóch frakcjach [2]. U chorych starszych, obciążonych schorzeniami współistniejącymi lub $z$ przeciwwskazaniami do radioterapii, stosuje się strategię watch and wait.

\section{Postępowanie u chorych na FL w zaawansowanych stadiach klinicznych $\mathrm{z}$ malą masa guza, bez objawów klinicznych}

Standardem postępowania u chorych na FL w zaawansowanych stadiach klinicznych (III, IV wg klasyfikacji Ann Arbor) z małą masą guza, bez objawów klinicznych jest strategia watch and wait, opracowana na podstawie wyników randomizowanych badań klinicznych, w których nie wykazano istotnej różnicy dotyczącej czasu OS u chorych leczonych $w$ momencie rozpoznania $\mathrm{FL} w$ porównaniu $\mathrm{z}$ chorymi leczonymi w okresie progresji choroby $[8,9]$. W badaniach tych strategię watch and wait porównywano $z$ chemioterapią lub stosowaniem interferonu [8], a w jednym $z$ największych stosowano monoterapię chlorambucylem [9]. Pierwsze badania, w których strategię obserwacji porównywano $\mathrm{z}$ zastosowaniem chemioimmunoterapii lub monoterapii rytuksymabem, miały charakter retrospektywny [10]. W 2014 roku opublikowano wyniki dwóch międzynarodowych, randomizowanych badań klinicznych 3. fazy, w których oceniano zastosowanie rytuksymabu u chorych na FL w zaawansowanych stadiach klinicznych bez wskazań do rozpoczęcia przeciwnowotworowego. 
W pierwszym z badań [11] uczestniczyło 463 chorych na FL, których poddano randomizacji do 3 grup:

- objętej strategią watch and wait - 187 chorych;

- poddanej leczeniu indukcyjnemu rytuksymabem $\left(375 \mathrm{mg} / \mathrm{m}^{2}, 4\right.$ podania w odstępach tyg.) - 84 chorych;

- poddanej leczeniu indukcyjnemu i leczeniu podtrzymującemu $\left(375 \mathrm{mg} / \mathrm{m}^{2}, 12\right.$ podań w odstępach 2-miesięcznych) - 192 chorych.

Ze względu na ograniczoną rekrutację chorych do grupy poddanej leczeniu indukcyjnemu wprowadzono poprawkę do protokołu dotyczącą jej wcześniejszego zamknięcia. Pierwszorzędowymi punktami końcowymi badania były czas do rozpoczęcia nowego leczenia (systemowej chemioterapii lub radioterapii) oraz jakość życia. Wyniki badania dowiodły, że czas do rozpoczęcia nowego leczenia był istotnie dłuższy u chorych objętych leczeniem podtrzymującym niż chorych $z$ grupy poddanej obserwacji. Nie wykazano jednak istotnego wpływu wcześniejszego rozpoczęcia leczenia na OS w porównaniu ze strategią watch and wait. Interesujące obserwacje przyniosło włączenie do analizy grupy chorych, których poddano tylko leczeniu indukującemu - wykazano brak istotnej różnicy dotyczącej czasu do rozpoczęcia nowego leczenia między grupą, która otrzymała jedynie cztery dawki rytuksymabu, a chorymi, którzy otrzymali dwanaście dawek rytuksymabu przez 2 lata stosowania leczenia podtrzymującego, co wskazuje na porównywalną skuteczność obu metod leczenia. Jakość życia chorych w odniesieniu do poziomu lęku i depresji była istotnie lepsza w grupie chorych, których poddano leczeniu podtrzymującemu, niż w pozostałych grupach. Rozpoczynanie leczenia przeciwnowotworowego wyłącznie $z$ tego powodu jest jednak dyskusyjne, ponieważ wydaje się, że, zamiast stosowania immunoterapii, należałoby większy nacisk położyć na dobrą relację lekarz-pacjent i wytłumaczenie choremu braku korzyści wynikających $z$ wcześniejszego rozpoczęcia leczenia w odniesieniu do czasu OS [11]. Drugie badanie, opisane przez Kahla i wsp. (badanie E4402, RESORT) [12], dotyczyło porównania leczenia indukcyjnego rytuksymabem $\left(375 \mathrm{mg} / \mathrm{m}^{2}\right.$, 4 podania w odstępach tygodniowych) i powtarzania go w przypadku progresji choroby oraz leczenia stosowanego w sposób ciągły $\left(375 \mathrm{mg} / \mathrm{m}^{2}\right.$ co 13 tygodniowych). W obu przypadkach leczenie stosowano do niepowodzenia leczenia definiowanego jako brak odpowiedzi na rytuksymab, rozpoczęcie alternatywnego leczenia, progresję w czasie krótszym niż
26 miesięcy lub wystąpienie objawów nietolerancji. Czas do niepowodzenia leczenia stanowił pierwszorzędowy punkt końcowy w tym badaniu. Do punktów drugorzędowych należały czas do rozpoczęcia leczenia cytotoksycznego i jakość życia związana ze zdrowiem. Podobnie jak w przypadku poprzedniego badania nie wykazano istotnej różnicy pod względem czasu do niepowodzenia leczenia między chorymi otrzymującymi rytuksymab w przypadku progresji a chorymi leczonymi w sposób ciągły. Mediana liczby dawek rytuksymabu wynosiła, odpowiednio, 4 i 18. Autorzy nie dowiedli istotnego wpływu rodzaju leczenia na jakość życia chorych ani na OS [12]. Przedstawione wyniki nie przemawiają za wcześniejszym rozpoczynaniem leczenia u chorych na FL w zaawansowanych stadiach bez wskazań do leczenia i za zmianą dotychczas obowiązujących standardów, zgodnie $z$ którymi leczenie należy rozpocząć u chorych spełniających kryteria GELF (Groupe d'Etude des Lymphomes Folliculaires) lub BNLI (British National Lymphoma Invstigation) [13] (tab. 1).

Wcześniejsze rozpoczęcie leczenia prawdopodobnie byłoby bardziej uzasadnione, gdyby na podstawie określonych markerów udało się wyodrębnić grupę chorych na FL o bardziej agresywnym przebiegu.

\section{Leczenie chorych na FL w zaawansowanych stadiach klinicznych}

Chłoniaki indolentne, w przeciwieństwie do chłoniaków agresywnych, w zdecydowanej większości przypadków są nieuleczalne dostępnymi metodami. Celem leczenia powinna być zatem skuteczna i trwała kontrola choroby (wydłużenie czasu do progresji choroby [PFS, progression-free survival] i OS) przy minimalnej toksyczności terapii i zachowaniu dobrej jakości życia. Należy przy tym brać pod uwagę potencjalne długoterminowe działania niepożądane i możliwość zastosowania w przyszłości kolejnych linii leczenia.

Standardem leczenia FL, zgodnie $z$ rekomendacjami ESMO i NCCN, jest obecnie chemioimmunoterapia przeciwciałami monoklonalnymi skierowanymi przeciw antygenowi CD20 (rytuksymabu) $[2,3]$ w schematach:

- R-CHOP (rytuksymab, cyklofosfamid, doksorubicyna, winkrystyna, prednizon);

- R-CVP (rytuksymab, cyklofosfamid, wikrystyna, prednizon);

- BR (bendamustyna, rytuksymab).

Wyniki wieloośrodkowych randomizowanych badań klinicznych 3. fazy wykazały, że dołączenie 
Tabela 1. Kryteria rozpoczęcia leczenia chorych na chłoniaka grudkowego według Groupe d'Etude des Lymphomes Folliculaires (GELF) i British National Lymphoma Invstigation (BNLI) (źródło [13])

Table 1. The criteria for starting treatment of patients with follicular lymphoma by the Groupe d'Etude des Lymphomes Folliculaires (GELF) and the British National Lymphoma Invstigation (BNLI) (source [13])

\begin{tabular}{|c|c|}
\hline GELF & BNLI \\
\hline Masa węzłowa lub pozawęzłowa $\geq 7 \mathrm{~cm}$ & Objawy ogólne lub świąd skóry \\
\hline Zajęcie $\geq 3$ miejsc węzłowych, każde $\geq 3 \mathrm{~cm}$ & Szybka uogólniona progresja chłoniaka \\
\hline Splenomegalia $>16 \mathrm{~cm}$ w badaniu CT & $\begin{array}{l}\text { Naciek w szpiku (stężenie Hb } \leq 10 \mathrm{~g} / \mathrm{dl} \text {, liczba WBC < } 3 \mathrm{G} / \mathrm{l} \text {, } \\
\text { liczba PLT }<100 \mathrm{G} / \mathrm{l} \text { ) }\end{array}$ \\
\hline Naciekanie/ucisk na narządy & Naciek narządów zagrażający życiu \\
\hline Wysięk do jamy opłucnej lub otrzewnej & Naciek wątroby lub nerek \\
\hline Cytopenie (liczba WBC $<1,0$ G/l i/lub liczba PLT $<100$ G/l) & Zmiany w kościach \\
\hline \multicolumn{2}{|l|}{ Liczba komórek chłoniaka we krwi > 5 G/l } \\
\hline \multicolumn{2}{|l|}{ Objawy ogólne } \\
\hline $\begin{array}{l}\text { Aktywność LDH > normy lub stężenie } \beta_{2} \text {-mikroglobuliny } \\
\geq 3 \mathrm{~g} / \mathrm{dl}\end{array}$ & \\
\hline
\end{tabular}

CT (computed tomography) - tomografia komputerowa; WBC (white blood cells) - krwinki białe; PLT (platelets) - płytki krwi; LDH (lactate dehydrogenase) - dehy-

rytuksymabu do schematów CVP (cyklofosfamid, wikrystyna, prednizon) i CHOP (cyklofosfamid, doksorubicyna, winkrystyna, prednizon) w istotny sposób wpływa na zwiększenie odsetków odpowiedzi i wydłużenie OS w porównaniu $z$ samą chemioterapią [14-16]. Schemat BR umieszczono $\mathrm{w}$ zaleceniach na podstawie wyników randomizowanych badań klinicznych, w których wykazano jego podobną skuteczność jak w przypadku schematów uznawanych za standard leczenia [17, 18]. Żaden $z$ przedstawionych schematów nie jest rekomendowany jako optymalny schemat $z$ wyboru; nie dowiedziono - jak dotąd - istotnej przewagi któregokolwiek z nich w odniesieniu do OS.

W badaniu FOLL05 [19] dokonano prospektywnego porównania skuteczności trzech schematów w leczeniu I linii chorych na FL: R-CHOP, R-CVP i R-FM (rytuksymab, fludarabina, mitoksantron). Całkowity odsetek odpowiedzi (ORR, overall response rate) oraz odsetek całkowitej remisji (CR) były zbliżone $\mathrm{w}$ trzech ocenianych grupach. Po 34 miesiącach obserwacji odsetek OS w całej grupie chorych wynosił $95 \%$, dlatego uznano, że na tym etapie nie był on wiarygodnym parametrem oceny skuteczności leczenia. Punktem pierwszorzędowym badania był czas do niepowodzenia leczenia (TTF, time to treatment failure). Skuteczność leczenia w odniesieniu do TTF i PFS była istotnie większa w przypadku schematu R-CHOP i R-FM niz R-CVP. Odsetki 3-letnich TTF i PFS wynosily odpowiednio: $46 \%$ i $52 \%$ (R-CVP), $62 \%$ i $68 \%$ (R-CHOP) oraz $59 \%$ i $63 \%$ (R-FM). Toksyczność schematu R-FM była istotnie więk- sza w odniesieniu do powikłań hematologicznych (granulocytopenia) oraz indukowania wtórnych nowotworów [19]. Aktualizacja wyników badania po 56 miesiącach obserwacji, przedstawiona w trakcie Zjazdu ASCO (American Society of Clinical Oncology) w 2014 roku, potwierdziła wcześniejsze dane - zarówno dotyczące większej skuteczności schematów R-CHOP i R-FM w odniesieniu do PFS i TTF, jak i istotnie większej toksyczności schematu R-FM. W świetle tych danych, zdaniem autorów, leczeniem $z$ wyboru I linii chorych na FL powinien być schemat R-CHOP [20]. Odmienne dane przyniosły wyniki przejściowej analizy badania Polskiej Grupy Badawczej Chłoniaków (PLRG-4), przedstawione w trakcie konferencji w Lugano w 2013 roku, w którym dokonano prospektywnego porównania skuteczności i tolerancji schematów R-CHOP i R-CVP w leczeniu 1. linii chorych na chłoniaki indolentne. Badana grupa obejmowała 270 chorych, w tym 99 chorych na FL i 98 chorych na MZL. Autorzy nie wykazali istotnych różnic dotyczących ani odsetków odpowiedzi ani czasu do progresji choroby, a schemat R-CHOP cechował się większą toksycznością [21]. $Z$ wyciąnnięciem ostatecznych wniosków $z$ tego badania należy oczywiście zaczekać na wyniki analizy końcowej. U wszystkich chorych uczestniczących w badaniu PLRG-4, w przeciwieństwie do badania FOLL05, po zakończeniu leczenia indukcyjnego stosowano leczenie podtrzymujące rytuksymabem, co może mieć wpływ na odmienne wyniki dotyczące czasów przeżycia.

Trzecim schematem zalecanym od niedawna jako standard leczenia I linii chorych na FL jest 
bendamustyna w połączeniu $z$ rytuksymabem. Prospektywne porównanie skuteczności schematów BR i R-CHOP w I linii leczenia chorych na chłoniaki indolentne lub chłoniaka $z$ komórek płaszcza było przedmiotem badania StiL przeprowadzonego przez Rummela i wsp. [17]. Badaną grupę stanowiło 534 chorych, w tym 279 chorych na FL. Pierwszorzędowym celem badania było wykazanie, że schemat BR cechuje się nie mniejszą skutecznością w odniesieniu do PFS niz schemat R-CHOP (badanie typu non-inferiority). Wyniki badania były bardzo korzystne dla schematu BR, ponieważ PFS po 45 miesiącach obserwacji było istotnie dłuższe (69,9 v. 31,2 miesiąca), a odsetek CR - istotnie większy (przy porównywalnym ORR) niż w przypadku schematu R-CHOP. Ponadto schemat BR cechował się istotnie mniejszą toksycznością w odniesieniu do powikłań hematologicznych 3.-4. stopnia (leukopenia, granulocytopenia), infekcyjnych (epizody infekcyjne, sepsa, zapalenie błon śluzowych jamy ustnej) oraz neurologicznych (parestezje). U chorych leczonych według schematu BR częściej natomiast występowały zmiany skórne (rumień, reakcje alergiczne). Nie obserwowano różnic dotyczących OS. Drugie badanie (BRIGHT), przeprowadzone w krajach Ameryki Północnej, obejmowało 447 chorych na chłoniaki indolentne lub chłoniaka $z$ komórek płaszcza, wśród których zdecydowaną większość (314 osób) stanowili chorzy na FL [18]. Po randomizacji, w leczeniu I linii, stosowano schemat BR lub schematy R-CHOP/R-CVP (zależnie od decyzji badacza). Było to również badanie typu non-inferiority, którego celem było wykazanie, że zastosowanie schematu BR pozwala uzyskać nie mniejszy odsetek CR, jak w przypadku schematów R-CHOP/R-CVP. W badaniu osiągnięto cel pierwszorzędowy; odsetek CR wynosił odpowiednio 31\% dla schematu BR i 25\% dla schematów R-CHOP/R-CVP. Nie zanotowano różnic dotyczących PFS ani OS. Stwierdzono natomiast istotnie większą poprawę jakości życia $\mathrm{u}$ chorych leczonych według schematu BR w porównaniu z R-CHOP [22]. Profil toksyczności był odmienny zależnie od zastosowanego schematu. W przypadku schematów R-CHOP/R-CVP istotnie częściej obserwowano utratę włosów i polineuropatię obwodową, natomiast w przypadku schematu BR - powikłania dermatologiczne oraz nudności i wymioty. Należy przy tym zaznaczyć, że o ile profilaktyka przeciwwymiotna $z$ zastosowaniem setronów była podobna u wszystkich chorych, o tyle u chorych leczonych według schematu R-CHOP znacznie częściej stosowano aprepitant. Nie obserwowano istotnych różnic dotyczących powikłań infekcyjnych, chociaż u chorych leczonych zgodnie ze schematem R-CHOP istotnie częściej obserwowano granulocytopenię 3.-4. stopnia, mimo że $\mathrm{w}$ tej grupie istotnie częściej niż w obu pozostałych stosowano czynniki stymulujące granulopoezę (G-CSF, granulocyte-colony stimulating factors). Wprawdzie wyniki badania BRIGHT nie były tak korzystne dla schematu BR, jak uzyskane w badaniu StiL, tym niemniej w obu przedstawionych badaniach wykazano podobną skuteczność schematu BR, jak schematów R-CHOP/R-CVP. Wyniki tych badań stały się podstawą do wprowadzenia bendamustyny w połączeniu $z$ rytuksymabem do standardów leczenia I linii chorych na FL. Bendamustyna może stanowić korzystną alternatywę dla schematów CHOP/CVP, pozwala bowiem uniknąć toksyczności wchodzących w ich skład leków (doksorubicyna, prednizon czy winkrystyna), co jest szczególnie istotne $u$ chorych $z$ niewydolnością serca, cukrzycą czy neuropatią. Niestety, bendamustyna nie jest obecnie zarejestrowana w leczenia I linii chłoniaków indolentnych; wniosek rejestracyjny został złożony do Europejskiej Agencji Leków (European Medicine Agency), a decyzja jest spodziewana w 2015 roku.

$\mathrm{W}$ żadnym $z$ wymienionych zaleceń (ESMO, NCCN) nie ma sugestii odnośnie do preferowanego sposobu leczenia I linii. Wybierając optymalny schemat, należy uwzględnić nie tylko jego skuteczność w odniesieniu do PFS czy OS, ale również toksyczność leków w poszczególnych schematach, wpływ leczenia na jakość życia, wiek chorych, stan wydolności fizycznej, choroby współistniejące i preferencje pacjenta.

Według zaleceń ESMO u chorych starszych, obciążonych schorzeniami wspólistniejącym, skuteczną i dobrze tolerowaną metodą może być zastosowanie skróconego cyklu immunochemioterapii $\mathrm{w}$ połączeniu $z$ pełnym cyklem immunoterapii rytuksymabem [2]. Można również zastosować monoterapię rytuksymabem, która pozwala uzyskać odpowiedź u około $70 \%$ chorych, a CR - u 30-40\% chorych na chłoniaki indolentne [23-25].

\section{Leczenie podtrzymujące po leczeniu I linii}

Zgodnie $z$ aktualnymi standardami leczenia u chorych na FL, u których uzyskano odpowiedź częściową lub całkowitą po leczeniu indukującym I linii, należy zastosować leczenie podtrzymujące rytuksymabem (12 dawek, $375 \mathrm{mg} / \mathrm{m}^{2}$ co 8 tygodni). Podstawą do wprowadzenia tych zaleceń były wyniki badania PRIMA — wieloośrodkowego badania randomizowanego 3. fazy, w którym wykazano, 
że leczenie podtrzymujące istotnie wydłuża PFS i czas do rozpoczęcia następnego leczenia przeciwnowotworowego oraz poprawia jakość odpowiedzi u chorych, u których uzyskano odpowiedź na leczenie indukujące [26]. Do badania zakwalifikowano 1217 chorych na FL ze wskazaniami do leczenia systemowego I linii, których poddano leczeniu według jednego $z$ trzech schematów (R-CHOP, R-CVP, R-FCM [rytuksymab, fludarabina, cyklofosfamid, mitoksantron]). Zdecydowana większość chorych była leczona według schematu R-CHOP (75\%), $22 \%$ otrzymało R-CVP, a $2 \%$ - R-FCM. Chorzy, u których uzyskano odpowiedź (CR/remisja częściowa [PR, partial remission]), byli następnie poddawani randomizacji do dwóch grup — objętej leczeniem podtrzymującym rytuksymabem podawanym w dawce $375 \mathrm{mg} / \mathrm{m}^{2}$ dożylnie do 8 tygodni przez 2 lata lub poddanej obserwacji. W pierwszej grupie było 505 chorych, a w grupie drugiej - 513. Po medianie czasu obserwacji wynoszącej 36 miesięcy odsetek chorych bez progresji był istotnie większy w grupie leczonej rytuksymabem i wynosil, odpowiednio, 74,9\% i 57,6\%. Ponadto, po 2 latach od randomizacji, $\mathrm{w}$ grupie leczenia podtrzymującego odsetek chorych $z$ CR lub niepotwierdzonym CR ( $\mathrm{uCR}$, unconfirmed $C R$ ) był istotnie większy niż w grupie obserwowanej $(71,5 \% v .52,2 \%)$, a zastosowanie leczenia podtrzymującego obniżało ryzyko progresji o 45\%. Najczęstszym działaniem niepożądanym związanym $z$ rytuksymabem były infekcje (stopni 2.-4.), przy czym nie stwierdzono negatywnego wpływu leczenia podtrzymującego na jakość życia. W trakcie zjazdu ASH (American Society of Hematology) w 2013 roku przedstawiono aktualizację wyników badania PRIMA dokonaną po 6 latach obserwacji, w której potwierdzono wcześniejsze wyniki dotyczące istotnie dłuższego PFS w grupie, w której stosowano leczenie podtrzymujące. Nie wykazano istotnego wpływu leczenia na OS i odpowiedź na leczenie II linii ani związanej z nim późnej toksyczności [27].

Leczenie podtrzymujące zaleca się obecnie u wszystkich chorych, u których uzyskano odpowiedź na leczenie I linii. Zadawane jest jednak pytanie, czy rzeczywiście powinno ono być stosowane u wszystkich chorych? Możliwe, że w przyszłości o kwalifikacji do leczenia podtrzymującego będą decydowały wyniki badania PET/CT lub ocena minimalnej choroby resztkowej (MRD, minimal residual disease). Wykazano, że uzyskanie remisji metabolicznej po leczeniu indukującym jest niezależnym czynnikiem prognostycznym w odniesieniu do progresji choroby $[28,29]$ oraz że PFS u chorych, u których stwierdzono obecność MRD po leczeniu indukującym, jest istotnie krótszy niż u chorych bez wykrywalnej MRD [30].

\section{Podsumowanie}

U chorych na FL w zaawansowanych stadiach klinicznych $z$ małą masą guza bez objawów klinicznych optymalnym sposobem postępowania pozostaje nadal stosowana strategia watch and wait. W przypadku wystąpienia wskazań do rozpoczęcia leczenia należy zastosować immunochemioterapię z zastosowaniem rytuksymabu, w którym zaleca się schematy: R-CHOP, R-CVP, RB. Wybór optymalnego schematu leczenia powinien zależeć od indywidualnej sytuacji klinicznej, z uwzględnieniem czynników zależnych zarówno od choroby, jak i od pacjenta.

\section{Piśmiennictwo}

1. A clinical evaluation of the International Lymphoma Study Group classification of non-Hodgkin's lymphoma. The Non-Hodgkin's Lymphoma Classification Project. Blood 1997; 89: 3909-3918.

2. Dreyling M., Ghielmini M., Marcus R. i wsp.; ESMO Guidelines Working Group. Newly diagnosed and relapsed follicular lymphoma: ESMO Clinical Practice Guidelines fordiagnosis, treatment and follow-up. Ann. Oncol. 2014; 25: iii76-iii82.

3. Zelenetz A.D., Gordon L.I., Wierda W.G. i wsp. Non-Hodgkin's lymphomas, version 2.2014. J. Natl. Compr. Canc. Netw. 2014; 12: 916-946.

4. Lowry L., Smith P., Qian W. i wsp. Reduced dose radiotherapy for local control in non-Hodgkin lymphoma: a randomised phase III trial. Radiother. Oncol. 2011; 100: 86-92.

5. Vaughan Hudson B., Vaughan Hudson G., MacLennan K.A. i wsp. Clinical stage 1 non-Hodgkin's lymphoma: long-term follow-up of patients treated by the British National Lymphoma Investigation with radiotherapy alone as initial therapy. Br. J. Cancer 1994; 69: 1088-1093.

6. Mac Manus M.P., Hoppe R.T. Is radiotherapy curative for stage I and II low-grade follicular lymphoma? Results of a long-term follow-up study of patients treated at Stanford University. J. Clin. Oncol. 1996; 14: 1282-1290.

7. Guadagnolo B.A., Li S., Neuberg D. i wsp. Long-term outcome and mortality trends in early-stage, Grade 1-2 follicular lymphoma treated with radiation therapy. Int. J. Radiat. Oncol. Biol. Phys. 2006; 64: 928-934.

8. Brice P., Bastion Y., Lepage E. i wsp. Comparison in low-tumor-burden follicular lymphomas between an initial no-treatment policy, prednimustine, or interferon alfa: A randomized study from the Groupe d'Etude des Lymphomes Folliculaires. Groupe d'Etude des Lymphomes de l'Adulte. J. Clin. Oncol. 1997; 15: 1110-1117.

9. Ardeshna K.M., Smith P., Norton A. i wsp. Long term effect of a watch and wait policy versus immediate systemic treatment for asymptomatic advanced-stage non-Hodgkin lymphoma: A randomised controlled trial. Lancet 2003; 362: 516-522. 
10. Solal-Celigny P., Bellei M., Marcheselli L. i wsp. Watchful waiting in low-tumor burden follicular lymphoma in the rituximab era: results of an F2-study database. J. Clin. Oncol. 2012; 30: 3848-3853.

11. Ardeshna K.M., Qian W., Smith P. i wsp. Rituximab versus a watch-and-wait approach in patients with advanced-stage, asymptomatic, non-bulky follicular lymphoma: an open-label randomised phase 3 trial. Lancet. Oncol. 2014; 15: 424-435.

12. Kahl B.S., Hong F., Williams M.E. i wsp. Rituximab extended schedule or retreatment trial for low-tumor burden follicular lymphoma: eastern cooperative oncology group protocol E4402. J. Clin. Oncol. 2014; 32: 3096-3102.

13. Lech-Marańda E. Chłoniak grudkowy. W: Krzakowski M., Warzocha K. (red.). Zalecenia postępowania diagnostyczno-terapeutycznego w nowotworach złośliwych - 2013 rok. Via Medica, Gdańsk 2013: 878-888.

14. Hiddemann W., Kneba M., Dreyling M. i wsp. Frontline therapy with rituximab added to the combination of cyclophosphamide, doxorubicin, vincristine, and prednisone (CHOP) significantly improves the outcome for patients with advanced-stage follicular lymphoma compared with therapy with CHOP alone: Results of a prospective randomized study of the German Low-Grade Lymphoma Study Group. Blood 2005; 106: 3725-3732.

15. Marcus R., Imrie K., Belch A. i wsp. CVP chemotherapy plus rituximab compared with CVP as first-line treatment for advanced follicular lymphoma. Blood 2005; 105: 1417-1423.

16. Marcus R., Imrie K., Solal-Celigny P. i wsp. Phase III study of R-CVP compared with cyclophosphamide, vincristine, and prednisone alone in patients with previously untreated advanced follicular lymphoma. J. Clin. Oncol. 2008; 26: 4579-4586.

17. Rummel M., Niederle N., Maschmeyer G. i wsp. Bendamustine plus rituximab versus $\mathrm{CHOP}$ plus rituximab as first-line treatment for patients with indolent and mantle cell lymphoma: an open-label, multicentre, randomised, phase 3 non-inferiority trial. Lancet 2013; 381: 1203-1210.

18. Flinn I.W., van der Jagt R., Kahl B.S. i wsp. Randomized trial of bendamustine rituximab or R-CHOP/R-CVP in first-line treatment of indolent NHL or MCL: the BRIGHT study. Blood 2014; 123: 2944-2952.

19. Federico M., Luminari S., Dondi A. i wsp. R-CVP versus R-CHOP versus R-FM for the initial treatment of patients with advanced-stage follicular lymphoma: results of the FOLL05 trial conducted by the Fondazione Italiana Linfomi. J. Clin. Oncol. 2013; 31: 1506-1513.

20. Luminari S., Dondi A., Marcheselli L. i wsp. Updated results of the FOLL05 phase III trial from the Fondazione Italiana Linfomi comparing R-CVP, R-CHOP, and R-FM in patients with advanced follicular lymphoma. J. Clin. Oncol. 2014; 32: abstrakt 8530.
21. Walewski J., Szpila T., Jurczak W. i wsp. First-line R-CVP versus R-chop induction therapy and maintenance rituximab for indolent lymphoma. A multicentre phase III randomized study PLRG-4 by the Polish Lymphoma Research Group. Hematol. Oncol. 2013; 31: 96-150.

22. Burke J.M., van der Jagt R.H., Kahl B.S. Differences in Quality of life between bendamustine plus rituximab compared with standard first-line treatments in patients with previously untreated advanced indolent non-Hodgkin's lymphoma or mantle cell lymphoma. Blood 2012; 120: abstrakt 155.

23. Colombat P., Salles G., Brousse N. i wsp. Rituximab (anti-CD20 monoclonal antibody) as single first-line therapy for patients with follicular lymphoma with a low tumor burden: clinical and molecular evaluation. Blood 2001; 97: 101-106.

24. Ghielmini M., Schmitz S.F., Cogliatti S.B. i wsp. Prolonged treatment with rituximab in patients with follicular lymphoma significantly increases event-free survival and response duration compared with the standard weekly $\times 4$ schedule. Blood 2004; 103: 4416-4423.

25. Witzig T.E., Vukov A.M., Habermann T.M. i wsp. Rituximab therapy for patients with newly diagnosed, advanced-stage, follicular grade I non-Hodgkin's lymphoma: a phase II trial in the North Central Cancer Treatment Group. J. Clin. Oncol. 2005; 23: 1103-1108.

26. Salles G., Seymour J.F., Offner F. i wsp. Rituximab maintenance for 2 years in patients with high tumour burden follicular lymphoma responding to rituximab plus chemotherapy (PRIMA): A phase 3, randomised controlled trial. Lancet 2011; 377: 42-51.

27. Salles G., Seymour J.F., Feugier P. i wsp. Updated 6 year follow-up of the PRIMA study confirms the benefit of 2-year rituximab maintenance in follicular lymphoma patients responding to frontline immunochemotherapy. Blood 2013; 121: abstrakt 509.

28. Trotman J., Fournier M., Lamy T. i wsp. Positron emission tomography computed tomography (PET-CT) after induction therapy is highly predictive of patient outcome in follicular lymphoma: analysis of PET-CT in a subset of PRIMA trial participants. J. Clin. Oncol. 2011; 29: 3194-3200.

29. Dupuis J., Meignan M., Julian A. i wsp. Significant prognostic impact of $[18 \mathrm{~F}]$ fluorodeoxyglucose-PET scan performed during and at the end of treatment with R-CHOP in high-tumor mass follicular lymphoma patients: a GELA-GOELAMS study. Bood 2011; 118: abstrakt 877.

30. Galimberti S., Luminari S., Ciabatti E. i wsp. Minimal residual disease after conventional treatment significantly impacts on progression-free survival of patients with follicular lymphoma: the FIL FOLL05 trial. Clin. Cancer Res. 2014; 20: 6398-6405. 